\title{
Distribution extension of Scinax aromothyella (Anura, Hylidae)
}

\author{
Gabriel Laufer ${ }^{1,2}$, Juan Manuel Piñeiro-Guerra ${ }^{1}$, Ramiro Pereira-Garbero', \\ Juan Manuel Barreneche ${ }^{I}$ \& Rosana Ferrero ${ }^{I}$ \\ ${ }^{1}$ Sección Zoología de Vertebrados, Facultad de Ciencias, Universidad de la República, \\ Iguá 4225, Montevideo, Uruguay. \\ ${ }^{2}$ Corresponding author: laufer@netgate.com.uy
}

LAUFER, G., PIÑEIRO-GUERRA, J.M., PEREIRA-GARBERO, R., BARRENECHE, J.M. \& FERRERO, R. Distribution extension of Scinax aromothyella (Anura, Hylidae). Biota Neotrop. 9(2): http://www. biotaneotropica.org.br/v9n2/en/abstract?short-communication+bn02709022009.

\begin{abstract}
Scinax aromothyella is a recently described hylid frog. Its distribution is not well known. There are records for Misiones, Argentina and for southeastern Uruguay. Here we report a new record of S. aromothyella from Aceguá, Cerro Largo Department, Uruguay (31 53'39' S and 54 9' 17' W), based in tadpoles collected on the 15 of August, 2007. This new record extends the distribution of S. aromothyella in approximately $100 \mathrm{~km}$ north from previous reports in Uruguay. The samples were collected in a site located $2 \mathrm{~km}$ away from the border line with Brazil, reinforcing the idea that $S$. aromothyella might occur in Rio Grande do Sul.
\end{abstract}

Keywords: Amphibia, neotropical, larva, disturbed habitat, temporal pond, hilly area.

LAUFER, G., PIÑEIRO-GUERRA, J.M., PEREIRA-GARBERO, R., BARRENECHE, J.M. \& FERRERO, R. Extensión de la distribución de Scinax aromothyella (Anura, Hylidae). Biota Neotrop. 9(2): http://www. biotaneotropica.org.br/v9n2/es/abstract?short-communication+bn02709022009.

Resumen: Scinax aromothyella es un anfibio hilido recientemente descripto y con distribución poco conocida. Existen registros de Misiones, Argentina, y del sureste de Uruguay. Reportamos en este trabajo un nuevo registro de S. aromothyella para el Departamento de Cerro Largo, Uruguay, localidad Aceguá (31 53'39"'S y 549' 17' W) basado en renacuajos colectados el 15 de agosto de 2007. Este registro extiende la distribución de S. aromothyella más de $100 \mathrm{~km}$ al norte de los registros previos en Uruguay. La cercanía a la frontera $(2 \mathrm{~km})$ refuerza la idea de la ocurrencia de esta especie en el sur de Brasil.

Palabras clave: Amphibia, neotropical, larva, disturbio, charco temporal, sierra. 


\section{Introduction}

Scinax aromothyella (Faivovich 2005) is a recently described small hylid frog, closely related and similar to Scinax berthae (Barrio 1962), belonging both to the Scinax catharinae species group (Faivovich 2002). It was described based on specimens from three localities in central and northern Province of Misiones, northeastern Argentina (Faivovich 2005). Later on, its distribution was extended to Treinta y Tres Department (Prigioni et al. 2005), and Maldonado Department (Kolenc et al. 2007), southeastern Uruguay.

$S$. aromothyella males calls on the emergent vegetation (predominantly Eryngium sp.), only during or immediately after heavy rains (Faivovich 2005, Borteiro et al. 2007). Moreover, the natural history of this species is little known. S. aromothyella inhabits hilly areas, about $500 \mathrm{~m}$ altitude, with scarce arboreal vegetation (Prigioni et al. 2005, Borteiro et al. 2007), and can be found in open areas in semi-permanent swamps.

It seems clear that the actual distribution of this species is far from being known. It was suggested by Faivovich (2005) that $S$. aromothyella might be distributed in some areas of the state of Rio Grande do Sul, Brazil, and later reports in southeastern Uruguay reinforce this idea. Moreover, Borteiro et al. (2007) suggested that $S$. aromothyella might be also widely distributed in hilly areas in Uruguay. As in other cases of poorly known species, more studies about $S$. aromothyella are needed.

The limited records of $S$. aromothyella consist in a limitation for biogeography studies. In this context, when adults are rarely collected, larval sampling could be an effective alternative to study species occurrences (McDiarmid \& Altig 1999). Tadpoles are easily collected, and their presence in water bodies usually last longer periods than adult exposure. But this tool has been widely ignored in many cases because of the lack of appropriated larval descriptions for many regions. Fortunately this is not the case for the present report because of the availability of proper tadpoles' descriptions and determination keys for most of the anuran species present in Uruguay and southern Brazil (e.g. de Sá et al. 1997, Kolenc et al. 2007). The aim of this note is to report new data on $S$. aromothyella distribution based in tadpoles' records from Aceguá, Cerro Largo, Uruguay.

\section{Material and Methods}

Tadpoles were collected, with a drag net of $5 \mathrm{~mm}$ mesh, in a temporal pond of 2,300 $\mathrm{m}^{2}$ area, and a maximum depth about $1 \mathrm{~m}$. The pond is located in a high disturbed area, a cattle farmland next to slaughterhouse facilities. The vertebrate community at this pond was solely represented by anurans. Other tadpoles found in the sample were Hypsiboas pulchellus, Scinax sp., Pseudis minutus and Dendropsophus minutus. S. aromothyella represents less than $0.6 \%$ of total tadpole density in the sample. At the same locality we sampled other ponds and creeks, in a diameter of $500 \mathrm{~m}$, but we didn't find any other $S$. aromothyella specimens. The specimens are fixed in 10\% formalin dilution and stored at the Vertebrate Zoology Collection, Facultad de Ciencias, Universidad de la República, Uruguay (ZVCB 16610).
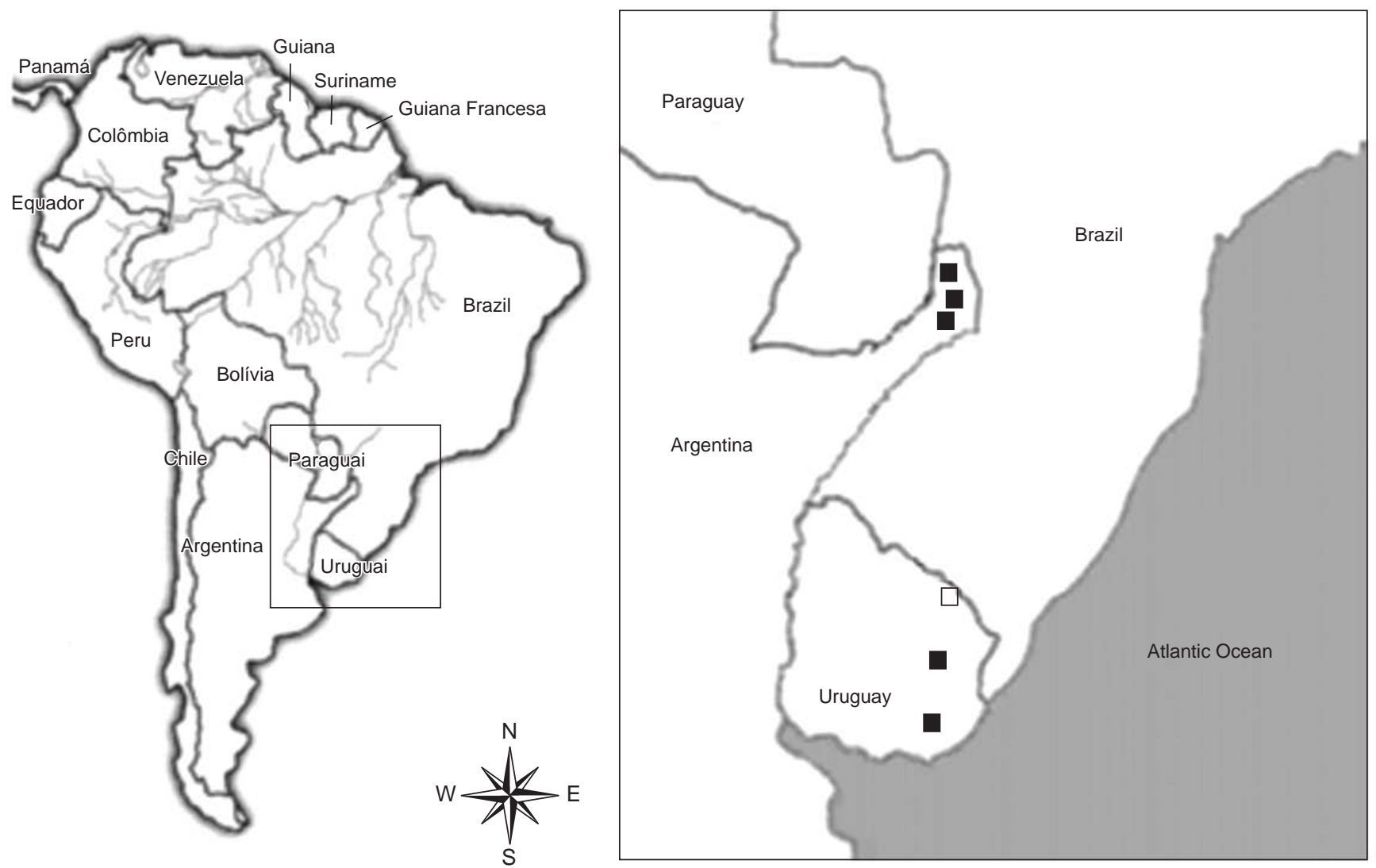

Figure 1. Distribution records for Scinax aromothyella. In the map the symbol a shows records from previous works (mentioned in the text) and the symbol $\square$ shows the site of the new record in present work.

Figura 1. Registros de distribución de Scinax aromothyella. En el mapa, el símbolo • indica los registros de reportes previos (ver texto) y el símbolo $\square$ el registro nuevo presentado en este artículo. 


\section{Results and Discussion}

Here we report a new record of $S$. aromothyella from Aceguá, Cerro Largo Department, Uruguay (31 '53'39' S and 54 9' 17'” W), based on 7 tadpoles collected on the 15 of August, 2007 (Figure 1). The tadpoles were identified following Kolenc et al. (2007), considering size, external morphology and oral disc configuration. This species is characterized by its slightly depressed body, a relatively long tail, large eyes and slightly expanded fins (Figure 2). The oral disc has a small dorsal gap in marginal papillation, a double row of marginal papillae at the posterior border of the oral disc, and many submarginal papillae at the sub-angular zone (Kolenc et al. 2007). The labial tooth row formula observed is $2(2) / 3$ and serrated jaw sheets (Figure 3). The tail muscle coloration in preserved specimens was also considered as a diagnostic character (Figure 2).

Collected specimens are in developmental Gosner's stages ranging from 25 to 27 , their total length is $\mathrm{TL}=22.65 \pm 3.15 \mathrm{~mm}$, and their body length is $\mathrm{BL}=7.53 \pm 1.18 \mathrm{~mm}$ (mean \pm standard deviation). Although of their early stages, the collected specimens are relatively large, and this is also a main characteristic of S. aromothyella tadpoles (De Sá et al. 1997, Kolenc et al. 2007).
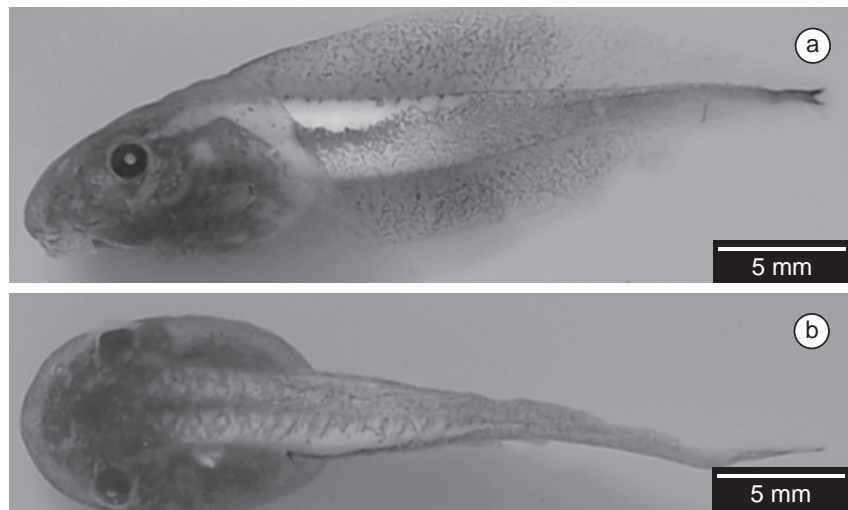

Figure 2. Tadpole of Scinax aromothyella preserved in $10 \%$ formalin, from Aceguá, Cerro Largo, Uruguay. a) in lateral and b) in dorsal view.

Figura 2. Larva de Scinax aromothyella de Aceguá, Cerro Largo, Uruguay, fijada en formol al $10 \%$. a) vista lateral y b) vista dorsal.

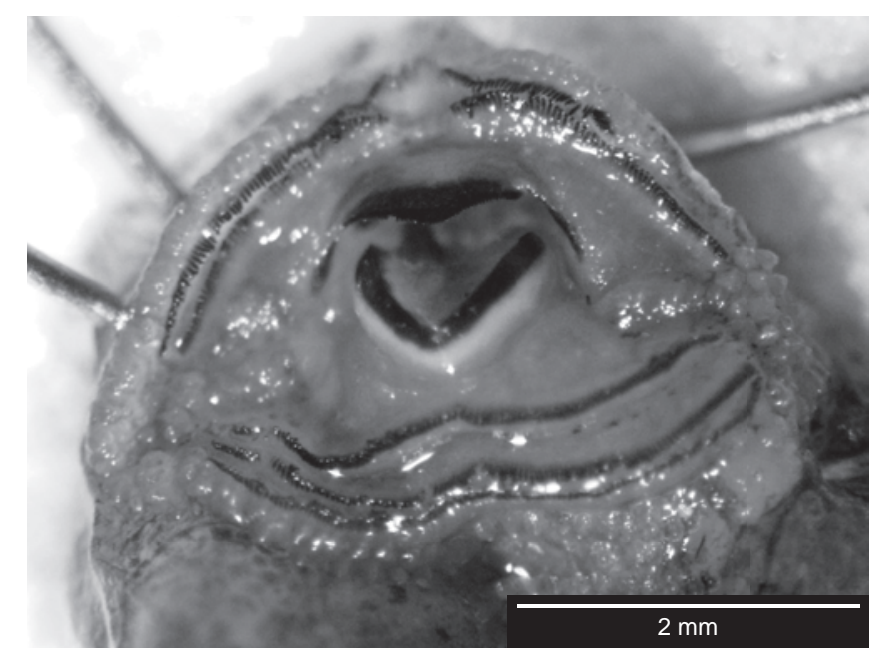

Figure 3. Opened oral disc of Scinax aromothyella tadpole preserved in 10\% formalin, from Aceguá, Cerro Largo, Uruguay.

Figura 3. Disco oral abierto de una larva de Scinax aromothyella de Aceguá, Cerro Largo, Uruguay, fijada en formol al $10 \%$.
Our observations confirm the idea that $S$. aromothyella breeds in semi permanent ponds at hilly open areas (Faivovich 2005, Borteiro et al. 2007). It is also the first report of this species at a high disturbed area. This new record extends the distribution of $S$. aromothyella in approximately $100 \mathrm{~km}$ north from previous reports in Uruguay. The samples were collected in a site located $2 \mathrm{~km}$ away from the border line with Brazil, reinforcing the idea that $S$. aromothyella might occur in Rio Grande do Sul. Further field research is needed in order to obtain a complete distribution map for this species, as an important tool for conservation and monitoring plans. Tadpole sampling could be an appropriate technique for sampling anurans witch adults are not easily detectable.

\section{Acknowledgements}

This work was supported by Programa de Desarrollo Tecnológico, Recursos Acuáticos PDT 71-10, Uruguay and by the Amphibian Specialist Group (UICN) Chester Zoo Seed Grant. The authors are grateful to Claudio Borteiro for the provided assistance in specimen's identification. Denise de Cerqueira Rossa-Feres and two anonymous referees made helpful comments which improved the manuscript.

\section{References}

BORTEIRO, C., NIETO, C. \& KOLENC, F. 2007. Amphibia, Anura, Hylidae, Scinax aromothyella: distribution extension and habitat. Check List, 3(2):98-99

DE SA, R.O., WASSERSUG, R.J. \& KEHR, A.I. 1997. Description of tadpoles of three species of Scinax (Anura, Hylidae). Herpetol. J. 7(1):13-17.

FAIVOVICH, J. 2002. A cladistic analysis of Scinax (Anura: Hylidae). Cladistics, 18(4):367-393.

FAIVOVICH, J. 2005. A new species of Scinax (Anura: Hylidae) from Misiones, Argentina. Herpetologica, 61(1):69-77.

KOLENC, F., BORTEIRO, C., TEDROS, M. \& PRIGIONI, C. 2007. The tadpole of Scinax aromothyella (Anura: Hylidae) from Uruguay. Stud. Neotrop. Fauna Environ. 42(3):175-180.

MCDIARMID, R.W. \& ALTIG, R. 1999. Research: materials and techniques. In Tadpoles: The Biology of Anuran Larvae (R.W. McDiarmid \& R. Altig, eds). University of Chicago Press, Chicago and London, p. 7-23.

PRIGIONI, C., BORTEIRO, C., TEDROS, M. \& KOLENC, F. 2005. Scinax aromothyella. Herpetol. Rev. 36(4):464. 